\title{
Erratum to: Psychological Resilience Building in Disaster Risk Reduction: Contributions from Adult Education
}

\author{
Martha Höfler
}

Published online: 4 June 2014

(C) The Author(s) 2014. This article is published with open access at Springerlink.com

Erratum to: Int J Disaster Risk Sci (2014) 5:33-40

DOI 10.1007/s13753-014-0009-2

The opening sentence of the Abstract of the article was incomplete in the first print edition of volume 5 , issue no. 1 . The sentence should have read "This article discusses three questions:".
Open Access This article is distributed under the terms of the Creative Commons Attribution License which permits any use, distribution, and reproduction in any medium, provided the original author(s) and the source are credited.

The online version of the original article can be found under doi:10.1007/s13753-014-0009-2.

M. Höfler ( $\square)$

Institute of Education and Culture, Chair of Adult Education, Friedrich Schiller University Jena, 07743 Jena, Germany

e-mail: martha.hoefler@uni-jena.de 